\title{
Days of change at the JLO
}

With the final issue of 2014, The Journal of Laryngology \& Otology team pass on our best wishes for the coming festive season and the future. We hope that readers have noticed a significant transition over the past two years in the content of The Journal, with more Review Articles and Main Scientific Articles, and fewer Clinical Records. The fact that we have been able to achieve this change reflects the quality of material being submitted to The Journal, for which we thank all of our authors. At present, we continue to publish about one-third of the material submitted to The Journal. We are particularly pleased with some of the high-quality review articles that we have been able to commission, as these articles reflect the latest opinion in the field of otolaryngology, and hopefully are of wide appeal. ${ }^{1-4}$ The sourcing of highquality review articles has been assisted by one of our Editorial Board, Vin Paleri. In the early part of 2015, we will be publishing important reviews on the subjects of tracheostomy in the UK and antiviral therapy for idiopathic facial paralysis (Bell's palsy). The latter article on Bell's palsy will challenge the accepted treatment of this condition, with conclusions that will be controversial.

The production of The Journal is very much a team effort. We are indebted to Rosamund Greensted, The Journal Managing Editor, for her tireless work, and her team of assistants and copy-editors. We also appreciate the dedication of Daniel Edwards and his team at our publishing partners, Cambridge University Press. We are very pleased with the success of our collaboration with the Australian Society of Otolaryngology, Head and Neck Surgery, which has been re-negotiated for a further three years. We are also pleased to announce that in 2015 we will become the official publication of the New Zealand and Malaysian Otolaryngology Societies. The work behind the scenes to secure these important partnerships has been expertly co-ordinated by The Journal Company Secretary, Andrew Chalk. The Journal relies on a relatively small group of Assistant Editors to undertake the vital work of peer review. As a result, our reviewers undertake proportionally more work than they would do for other journals, for which we are extremely grateful.

The year 2014 has also seen the appointment of a new Web Editor, Stephen Jones, who takes over from Vik Veer next year. We thank Vik for all his work on behalf of The Journal. It has always been our intention to develop the www.jlo.co.uk website into an independent educational resource. Visitors to the website will notice an enlarging video library, a comprehensive events calendar and links to journal articles.

My final duty this year is a sad one. Mike Hellyar, who for many years was The Journal Company Secretary, has sadly recently passed away. Mike moved to The Journal from the Royal Society of Medicine, and served The Journal well until his retirement in 2010. He will be remembered not only as an expert Company Secretary, but a good friend, full of kindness, and a perfect gentleman.

\section{ROBIN YOUNGS \\ EDWARD FISHER \\ Senior Editors}

References

1 Sivayoham E, Saunders R, Derby B, Woolford T. Current concepts and advances in the application of tissue engineering in otorhinolaryngology and head and neck surgery. J Laryngol Otol 2013;127:114-20

2 Hörmann K, Sadick H. Role of surgery in the management of head and neck cancer: a contemporary view of the data in the era of organ preservation. J Laryngol Otol 2013;127:121-7

3 Farboud A, Crunkhorn R, Trinidade A. 'Wind turbine syndrome': fact or fiction? J Laryngol Otol 2013;127:222-6

4 Sethi N, Kane J, Condon L. Creutzfeldt-Jakob disease and ENT. J Laryngol Otol 2013;127:1050-5 